\title{
Detection and treatment of HIV and hepatitis virus infections in Swiss correctional facilities
}

Gerlich, M G ; Frick, Ulrich ; Pirktl, L ; Uchtenhagen, Ambros

\begin{abstract}
OBJECTIVES: The aim of the study was to obtain an overview on diagnostic and therapeutic activities concerning hepatitis A, B, C virus and HIV in Swiss prisons.METHODS: A standardized questionnaire was sent to 91 prisons in the German and Italian speaking parts in October 2004; 41 institutions (45\%) answered the questionnaire.RESULTS: In almost all prisons serological examinations were not done routinely, but were provided when demanded by inmates or recommended by the medical service. Vaccination against hepatitis A or B infection and initiation of antiviral therapy was possible in most institutions.CONCLUSIONS: Most of the prisons investigated offered diagnostic and antiviral treatment for hepatitis virus and HIV infections. A reported problem was the discontinuation of ongoing treatments or vaccination cycles after discharge. In some cases deficient funding was an obstacle.
\end{abstract}

DOI: https://doi.org/10.1007/s00038-008-6014-8

Posted at the Zurich Open Repository and Archive, University of Zurich ZORA URL: https://doi.org/10.5167/uzh-10001

Journal Article

Published Version

Originally published at:

Gerlich, M G; Frick, Ulrich; Pirktl, L; Uchtenhagen, Ambros (2008). Detection and treatment of HIV and hepatitis virus infections in Swiss correctional facilities. International Journal of Public Health, 53(5):268-271.

DOI: https://doi.org/10.1007/s00038-008-6014-8 


\title{
Detection and treatment of HIV and hepatitis virus infections in Swiss correctional facilities
}

\author{
Miriam G. Gerlich ${ }^{1}$, Ulrich Frick ${ }^{1,2}$, Lynn Pirkt| ${ }^{1}$, Ambros Uchtenhagen ${ }^{1}$ \\ ${ }^{1}$ Research Institute for Public Health and Addiction, Zurich, Switzerland \\ ${ }^{2}$ Carinthia University of Applied Sciences, Feldkirchen, Austria
}

Submitted: 25 January 2006; Revised: 18 July 2007, 02 June 2008; Accepted: 11 June 2008

Published Online First: 29 September 2008

\section{Summary}

Objectives: The aim of the study was to obtain an overview on diagnostic and therapeutic activities concerning hepatitis A, B, $C$ virus and HIV in Swiss prisons.

Methods: A standardized questionnaire was sent to 91 prisons in the German and Italian speaking parts in October 2004; 41 institutions ( $45 \%$ ) answered the questionnaire.

Results: In almost all prisons serological examinations were not done routinely, but were provided when demanded by inmates or recommended by the medical service. Vaccination against hepatitis A or B infection and initiation of antiviral therapy was possible in most institutions.

Conclusions: Most of the prisons investigated offered diagnostic and antiviral treatment for hepatitis virus and HIV infections. A reported problem was the discontinuation of ongoing treatments or vaccination cycles after discharge. In some cases deficient funding was an obstacle.

Keywords: Hepatitis A virus infections - Hepatitis B virus infections Hepatitis C virus infections - Inmates - Prisons.

Switzerland has approximately 170 prisons, 24 of which are for incarceration periods longer than six months. In 2003, 5266 persons were arrested. Among these, 2637 persons (50\%) were not yet sentenced: 1710 in pretrial detention, 301 awaiting repatriation and 626 in other forms of custody ${ }^{1}$. International studies have reported seroprevalence rates in incarcerated persons of 1.2 to $6.6 \% \mathrm{HIV}^{2-5}, 22$ and $49 \%$ hepatitis $\mathrm{C}$ virus (HCV) and 6 to $25.2 \%$ resolved or ongoing hepatitis B virus (HBV) infection ${ }^{2,3,5,6}$. Despite these significant rates, there is currently no federal ordinance on the prevention, diagnosis and treatment of HIV and hepatitis virus infections in Swiss prisons ${ }^{7}$. Recently guidelines have been deemed necessary by experts ${ }^{8}$. In Switzerland no extensive HIV or HCV prevalence studies in the correctional setting are available. One of the aims of our study was to estimate the recent prevalence of HIV and HCV infections on the basis of staff information. The main goal of this survey was to report on the present provision of screening and treatment for serious infectious diseases like HIV and HCV infections in Swiss correctional facilities.

\section{Methods}

\section{Study population}

This study targeted pretrial detention penitentiaries and facilities, in the German and Italian speaking parts of Switzerland. Institutions for inmates exclusively awaiting repatriation to their country of origin were not included in this study, nor were 24 French speaking facilities. Addresses of all institutions included in the study were provided by the Swiss Federal Statistical Office.

A questionnaire was sent to the directors of the correctional facilities on October 18, 2004. It consisted of two parts: i) Screening and treatment of HIV, hepatitis virus infections and $\mathrm{TB}$ and ii) preventive measures provided for HIV and HCV. The findings from the second section have already been published ${ }^{9}$. A standardized reminder letter was sent to non-responding institutions four weeks after the initial letter. Of the 91 facilities contacted, 63 responded. 22 institutions (24\%) stated in a short note that a lack of time hindered them in answering the questionnaire. 41 institutions returned a questionnaire, resulting in a response rate of $45 \%$ (41/91) for the survey period running from October to the end of December 2004. 


\begin{tabular}{lllll}
\hline Possible reason & Chronic hepatitis virus infection & HIV infection & \\
\hline & $\mathrm{n}($ valid \%) & $\mathrm{n}$ missing values & $\mathrm{n}$ (valid \%) & $\mathrm{n}$ missing values \\
No internal health service & $4(22)$ & 23 & $3(18)$ & 24 \\
No covering of the costs & $5(25)$ & 21 & $3(17)$ & 23 \\
No external health service & $3(17)$ & 23 & $3(18)$ & 24 \\
\hline
\end{tabular}

Table 1. Reasons for not initiating a pharmaceutical therapy in eligible patients $\mathrm{N}=41$.
Medical staff and directors each answered $37 \%$ of the questionnaires (15/41), and 9\% (4) were completed by others (e.g. direction social service). As it was optional to provide respondent details (such as profession), this contributed to the lack of information on the professional background in $17 \%$ of the questionnaires (7/41). Our instructions did not limit answers to only medical staff; directors could choose to fill out the questionnaires themselves or pass them on to the appropriate personnel.

\section{Statistical analysis}

Returned questionnaires were entered into SPSS 11.5 using a double data entry procedure. Differences in proportions were tested by Chi-square statistics. The risk of type I error was set to 0.05 and, due to the exploratory nature of this study, was not adjusted for multiple testing. Percentages were given using an item-wise exclusion of missing values. Thus, the reported $\mathrm{N}$ varies in the description of the results.

\section{Results}

We asked the staff about the type and size of their correctional facility. 24 of the responding institutions provided places for sentenced and pretrial detention for men, 19 institutions had pretrial detention places for women and 9 facilities had places for sentenced women. A total of 2540 places were represented by all responding institutions. At the time of the study, 2443 places were occupied $(96 \%)$. Half of the institutions reported a capacity less than 36 places, and three quarters of the institutions reported a capacity of less than 79 places (range 5-462 places).

\section{Estimated prevalence of HIV and $\mathrm{HCV}$}

The staff of the facilities were asked to report the prevalence of HIV and HCV among the inmates, using established reporting systems or to estimate the prevalence rates based on their experience. For HIV, the weighted mean of the prevalence rates was $2.5 \%$ (CI 2.0-2.9). This number was equally based on estimations and on actual serological tests, which, however, referred to known cases and were usually not based on routine screening. The weighted mean of $\mathrm{HCV}$ prevalence rates was $7.0 \%$ (CI 6.2-7.8). The reported prevalence rates were based on estimations in about $60 \%$ of the facilities and in about $40 \%$ on identified cases.

\section{Screening}

Almost all institutions (39/40) offered HIV, HBV and HCV serological testing. In 3 institutions inmates could not be tested for HAV; we have no explicit information why this was so. The main reasons reported for not conducting serological examinations (aside from denied patient consent) were a lack of internal medical services (6/23) and an absence of any medical examination (8/26). Other reasons included insufficient cost coverage (3) and short periods of incarceration (2). Moreover, it was mentioned that in some cases, tests of earlier institutions were consulted (1) and that the effort and the consequences of testing were not clear (1).

In 63 to $88 \%$ of the institutions, serological tests were done on the request of the inmate, and in 46.2 to $61 \%$ on the recommendation from the prison doctor. Routine serological testing for HIV, HBV and HCV for all consenting inmates was done in only one institution. No institution routinely tested for HAV.

\section{Treatment}

In $90 \%$ (36/40) of the institutions the inmates had the opportunity to receive HIV antiviral therapy. For chronic HCV and chronic HBV infections, 34 and 35 out of 40 institutions, offered antiviral therapy respectively ( $85 \%$ and $88 \%$ ). Of the 6 institutions that stated that it was not possible to provide treatments for all chronic infections, 3 stated that they transferred patients to other places when such treatments are necessary, while 2 others stated that the continuation of a treatment is possible, but that they normally do not initiate it; one institution did not comment on this.

In all facilities, the diagnosis from the presiding doctor is required to initiate pharmacotherapy (35/35). In three institutions, a stay between 6 and 12 months was also a condition for initiating the treatment for chronic hepatitis virus infection. In addition, two institutions also mentioned an incarceration period of more than 6 months as a necessary condition for initiating the treatment for HIV. 


\begin{tabular}{llll}
\hline Funding agency & Yes & No & \\
\hline & $\mathrm{n}($ valid \%) & $\mathrm{n}$ (valid \%) & $\mathrm{n}$ missing values \\
Health insurance & $27(93)$ & $2(7)$ & 12 \\
$\begin{array}{l}\text { Cantonal department } \\
\text { of justice }\end{array}$ & $17(59)$ & $12(41)$ & 12 \\
$\begin{array}{l}\text { Facility } \\
\text { Inmate pays }\end{array}$ & $12(56)$ & $14(44)$ & 15 \\
\hline
\end{tabular}

Table 2. If vaccinations are performed (HBV, HAV), who is paying them? (More than one funding source is possible) $\mathrm{N}=41$.
Reasons for not offering pharmaceutical therapy are shown in table 1. For hepatitis virus infections, funding problems were an obstacle for starting an antiviral therapy in more institutions than for HIV.

In 33/38 institutions ( $87 \%$ ) patients who started antiviral therapy during imprisonment were transferred to continuing treatment programs after being released: As an open question, the reasons for not arranging a transfer to a continued treatment place were asked for. A reason mentioned by 4 institutions was that the incarcerated person was considered responsible to contact a medical service himself after release. Another response was that the maintenance of therapy is difficult when the inmate is homeless or has no family doctor. Other reasons included the absence of legal regulations, repatriation outside Switzerland (transfer in such cases is sometimes not possible) and a too short period of imprisonment.

\section{Vaccinations against $H A V$ and $H B V$}

Most of the institutions provided vaccinations against hepatitis A $(30 / 39,77 \%)$ and hepatitis B $(32 / 40,80 \%)$. They were provided through either the request of the inmate $(26 / 29)$ or the prison doctor's recommendation (26/32).

There are different agencies supporting vaccinations financially (table 2). In most institutions, health insurance is mentioned as a possible funding source $(27 / 29$, $93 \%$ ). In 9/24 institutions $(38 \%)$ the inmates themselves have to pay the costs in some cases.

The main reason for not providing vaccinations, after inmate rejection, was that the costs were not covered. This was stated by $6 / 28$ institutions $(21 \%)$. A shortage of staff was also mentioned in $2 / 27$ institutions ( $7 \%$ ). Further reasons mentioned included the lack of medical employees in the institution (2), an insufficient number of infected persons over the years (1), no explicit recommendation (1), no indication (1), and too short of an imprisonment period (4).

If a cycle of vaccination (two doses for HAV and three doses for HBV) was initiated but unfinished at discharge, 24/36 institutions $(67 \%)$ transferred their inmates to a service where the vaccination cycle could be finished. However, for 12 institutions $(33 \%)$ this was not the case. The reasons for not transferring an inmate are similar to the situation with initiated therapies.

In order to ensure the transfer after discharge, one institution mentioned that the effort of the prison staff to find an appropriate treatment place should be financed. Also, searching for a doctor who is willing to continue treatment has been identified as a "tedious" process.

\section{Discussion}

In this study, 41 Swiss prisons answered our questionnaire. It is not known in all cases who answered the questionnaire, i.e. medical doctors, directors or other professions. Yet due to the general nature of the questions this should not have generated significant inaccuracy. Achievements as well as deficits were reported. However, it remains uncertain whether the findings for the participating institutions can be extended to those who did not respond, or were not included (24 institutions in the French speaking region). It is also possible that questionnaires may have been rejected in order to avoid the exposure of an unfavorable situation, however there was no indication for this. Despite these limitations, this study gives a first overview, and may be helpful for further research on this important topic.

The staff of the prisons questioned estimated HIV and HCV infections to be quite frequent among their inmates (prevalence rates $2.5 \%$ for $\mathrm{HIV}$ and $7 \%$ for $\mathrm{HCV}$ infections). Compared to inmate populations in other countries, this prevalence seems to be lower, especially for HCV infections. However, a noted limitation of this data is that it is based on estimated prevalence rates and not on systematic surveys with serological testing of all inmates. In almost all responding institutions, tests for hepatitis $\mathrm{A}, \mathrm{B}$ and $\mathrm{C}$ virus and HIV infections were available, but testing was primarily done only if requested by the inmate or recommended by the prison doctor. Thus, the prevalence rates may have been underestimated.

Most of the institutions were able to provide antiviral therapy for HIV or chronic hepatitis B or C infection, however others 
did not due to a lack of doctors, or because the costs were not covered. However, to draw clear conclusions concerning insufficient medical staff or funding for therapies, more specific information on the special situations has to be collected. Standards of the Council of Europe require that inmates have access to medical care equal to that of patients in the outside community $^{10,11}$. Nevertheless, it seems reasonable that in institutions where inmates only stay short time (e.g. transitional sentence) longterm antiviral therapy is not initiated when there is no acute need.

Of the institutions questioned, $77 \%$ respectively $80 \%$ offered vaccinations against $\mathrm{HAV}$ and $\mathrm{HBV}$. The main reason why vaccinations were not always carried out was the lack of staff or funding. Furthermore, it was stated that explicit guidelines for vaccinations in Swiss prisons do not exist. Indeed, Switzerland has no recommendation to vaccinate prisoners against hepatitis A or $\mathrm{B}^{12-14}$. The maintenance of an already-initiated antiviral therapy or the completion of a vaccination cycle after release of an inmate is still unsatisfactory in Swiss prisons. This situation can only be improved if health institutions within and outside of the prison establish procedures on how to cooperate, exchange information on the inmates, and reach an agreement on cost coverage. There is an urgent need to increase awareness on these issues and to identify where recommendations are needed.

\section{Acknowledgements}

We express appreciation to the staff of the correctional facilities for participation in this study. As well, we would like to thank F. Kanteres of the University of Toronto for the English copy editing of the text and valuable comments. This research was partly supported by ESSEX Chemie AG.

\section{References}

1. Bundesamt für Justiz, Sektion Straf- und Massnahmenvollzug. Der Strafvollzug in der Schweiz. Bern: Bundesamt für Justiz, 2006:1-20.

2. Macalino G, Vlahov D, Sanford-Colby S, et al. Prevalence and incidence of HIV, hepatitis $B$ virus, and hepatitis $C$ virus infections among males in Rhode Island prisons. American Journal of Public Health 2004;94(7):1218-23.

3. Solomon L, Flynn C, Muck K, Vertefeuille J. Prevalence of HIV, syphilis, hepatitis B, and hepatitis $\mathrm{C}$ among entrants to Maryland correctional facilities. Journal of Urban Health 2004;81(1):25-37.

4. Maruschak L. HIV in Prisons, 2001: Bureau of Justice Statistics Bulletin. Washington D.C.: U.S. Department of Justice, January 2004.

5. Long J, Allwright S, Barry J, et al. Prevalence of antibodies to hepatitis B, hepatitis C, and HIV and risk factors in entrants to Irish prisons: a national cross sectional survey. British Medical Journal 2001;323:1-6.
6. Baillargeon J, Wu H, Kelley M, Grady J, Linthicum L, Dunn K. Hepatitis C seroprevalence among newly incarcerated inmates in the Texas correctional system. Public Health 2003;117:43-8.

7. Künzli J, Achermann A. Gesundheitsrelevante Rechte inhaftierter Personen im Bereich des Schutzes vor Infektionskrankheiten und Kompetenzen des Bundes zu ihrer Durchsetzung. Bern: Universität Bern;2007:1-57.

8. Achermann C, Hostettler U. Infektionskrankheiten im Strafvollzug. Rapid Assessment der Gesundheitsversorgung. Fribourg: Universität Freiburg Schweiz \& Swiss Forum for Migration and Population Studies, 2007:1-55.

9. Gerlich M, Frick U, Pirktl L, Uchtenhagen A. Prävention von HIV- und HepatitisvirusInfektionen in Schweizer Untersuchungshaftund Strafvollzugsanstalten. Suchtmagazin 2005;31(2):14-8.

10. European Committee for the Prevention of Torture and Inhuman or Degrading Treatment or Punishment (CPT). The CPT standards. "Substantive" sections of the CPT's General Reports. Strasbourg: Council of Europe, Rev. 2006:29-38.
11. Council of Europe. Recommendation No. $R$ (98) 7 concerning the ethical and organisational aspects of health care in prison. Committee of Ministers; 1998 (accessed July 14 ${ }^{\text {th }}$ at https:// wcd.coe.int)

12. Bundesamt für Gesundheit. Empfehlungen zur kombinierten Hepatitis A - und Hepatitis B Impfung. Bern: Bulletin vom 27.01.1997.

13. Bundesamt für Gesundheit. Empfehlungen zur Hepatitis-A-Prävention in der Schweiz. Bern: 2007.

14. Bundesamt für Gesundheit. Empfehlungen zur Hepatitis-B-Impfung. Bern: 1997.

Address for correspondence

Miriam Gerlich, MPH

Research Institute for Public Health and

Addiction

Konradstrasse 32, P.O. Box

8031 Zurich, Switzerland

E-mail: miriam.gerlich@isgf.uzh.ch
To access this journal online: http://www.birkhauser.ch/IJPH 